\title{
IAMJ
}

INTERNATIONAL

AYURVEDIC

MEDICAL JOURNAL

Research Article

ISSN: 2320-5091

Impact Factor: 6.719

\section{PHARMACEUTICAL STANDARDIZATION OF PRADARANTAKA YOGA}

\author{
Alukuru Harsitha ${ }^{1}$, G. Ramesh Babu ${ }^{2}$, Badari Narayana ${ }^{3}$, Ch. Sridurga ${ }^{4}$ \\ ${ }^{1} \mathrm{PG}$ Scholar Final year, ${ }^{2}$ Associate Professor, ${ }^{3} \mathrm{PG}$ Lecturer, ${ }^{4}$ Professor and HOD \\ Dept. of Rasa Shastra and Bhaishjya Kalpana, S.V Ayurvedic College, TTD, Tirupati, \\ Andhra Pradesh, India
}

Corresponding Author: alukuruharshitha@gmail.com

\section{https://doi.org/10.46607/iamj06p6012021}

(Published online: November 2021)

Open Access

(C) International Ayurvedic Medical Journal, India 2021

Article Received: 17/10/2021 - Peer Reviewed: 17/11/2021 - Accepted for Publication: 19/11/2021

Check for updates

\begin{abstract}
Rasa Shastra is the pharmaceutical branch of Ayurveda. As with any other medical system, the success of Ayurvedic treatment also depends upon the quality of medicine prescribed to the patient. An integral part of Rasa Shastra lies in the successful pharmaceutical process. Rasaoushadis are the potent Ayurvedic preparations mainly containing metals and minerals. These Oushadis possess a wide range of therapeutic efficacy and are considered superior because of their qualities like small dose, quick action, palatability and longer shelf life. Pradarantaka Yoga is an important Rasa Oushadi described in Rasa Tantra Sara Va Siddha Prayoga Sangraha (part_2)Streeroga Prakaranam indicated in Rakta Pradara. Pradarantaka Yoga contains Gairika and Amalaki Swarasa. The pharmaceutical procedures adopted in this study are Shodhana, Bhavana, Swarasa Nirmana and preparation of Vati of Pradarantaka Yoga. The specific pharmaceutical blend of these contents can result in a more effective formulation. Till now, no research work has been carried out to standardize this formulation. Therefore, the present study has been planned to standardize the method of preparation of Pradarantaka Yoga according to the method explained in the classical literature.
\end{abstract}

Keywords: Pradarantaka Yoga, Shodhana, Swarasa Nirmana, Standardization. 


\section{INTRODUCTION}

Nature possesses immensely valuable and powerful medicines in the form of metals, minerals and plants. However, most of the drugs as such are not absorbable into the biological system, until and unless they undergo certain modifications. Some specialized techniques are adopted to make these drugs absorbable and therapeutically viable. The drug manufacturing processes of Ayurveda are included in the discipline of Rasa Shastra and Bhaishajya Kalpana. Mineral materials as such are claimed to be toxic by Ayurvedic Rasa texts. By adopting specialized pharmaceutical procedures like Shodhana, Marana, Jarana, Murcchana etc, they are converted into nontoxic, safe and potent therapeutic forms.

Pradarantaka Yoga is one of the Herbo-mineral formulation mentioned in Rasa Tantra Sara Va Siddha Prayoga Sangraha(part_2)- Streeroga prakaranam,[1] which contains Gairika and Amalaki Swarasa. Shodhana, Bhavana, Swarasa Nirmana and the preparation of Vati of Pradarantaka Yoga are the main pharmaceutical procedures adopted in the preparation of Pradarantaka Yoga. Standardization of Ayurvedic drugs at various levels starting from the selection and collection of raw material to the final product is essential to produce a safe and efficacious drug. Therefore, in the present study, an effort has been made to highlight the significance of these pharmaceutical procedures and to standardize the method of preparation of Pradarantaka Yoga.

\section{AIM AND OBJECTIVES}

Pharmaceutical standardization of various steps involved in the preparation of Pradarantaka Yoga.

\section{MATERIALS AND METHODS}

Chief reference: Rasa Tantra Sara Va Siddha Prayoga Sangraha (part_2)-Streeroga prakaranam.

The entire preparation of Pradarantaka Yoga was carried out in the Department of Rasa Shastra and Bhaishajya Kalpana, TTD's S.V. Ayurvedic College, Tirupati, Andhra Pradesh.

The entire pharmaceutical study was carried out in four stages

Stage-I

- Gairika Shodhana

\section{Stage-II}

- Amalaki Swarasa Nirmana

\section{Stage-III}

- Bhavana of Shudha Gairika with Amalaki Swarasa Stage-IV

- Preparation of Vati of Pradarantaka Yoga

Pradarantaka Yoga preparation

- Materials: Gairika - 1400g

Amalaki Swarasa - Q.S

- Method/ Principle: Shodhana, Amalaki Swarasa Nirmana, Bhavana.

- Apparatus: Khalwayantra, Gas stove, Iron ladle, Steel vessel, Cloth, Spoon steel vessel, tray and steel cutter.

\section{Procedure}

Shodhana of Gairika was carried out by tking fine powder of Gairika in a stainless-steel vessel and added with sufficient quantity of ghee and placed over a mild fire. It is fired properly until it attains a brick red colour (Istika varna). It is then taken in khalvayantra, made of fine powder and stored in an airtight container. Fresh Amalaki was collected and washed it was then cut into small pieces, seed should be discarded and pounded in khalvayantra to make a paste. Swarasa was extracted by squeezing the paste of Amalaki through a clean cloth. Amalaki Swarasa was collected in a beaker. Shodita Gairika was taken in Khalwayantra and Amalaki Swarasa was added and triturated. Bhavana was carried out 21days Triturated was done until it attains Vatilakshana. Paste of Homogenous mixture was made into $750 \mathrm{mg}$ Vati by rolling the mixture between thumb and index finger. Vati was dried under shade and stored in a glass container.

\section{OBSERVATIONS:}

Asuddha Gairika was light brick red colour; its consistency was rough, lustrous and solid. After $1^{\text {st }}$ Bhavana with Amalaki Swarasa, consistency changed into soft, bright and semisolid. After $21^{\text {st }}$ Bhavana with Amalaki Swarasa, the consistency obtained was soft, bright, very sticky and semisolid. Shuddha Gairika was brick red in colour, soft, lustreless and fine inconsistency. 
After Bhavana the final product was smooth,blackish-red in color. The paste was nonsticky when rolled between the thumb and index finger. Blackish red-coloured small pills were prepared.

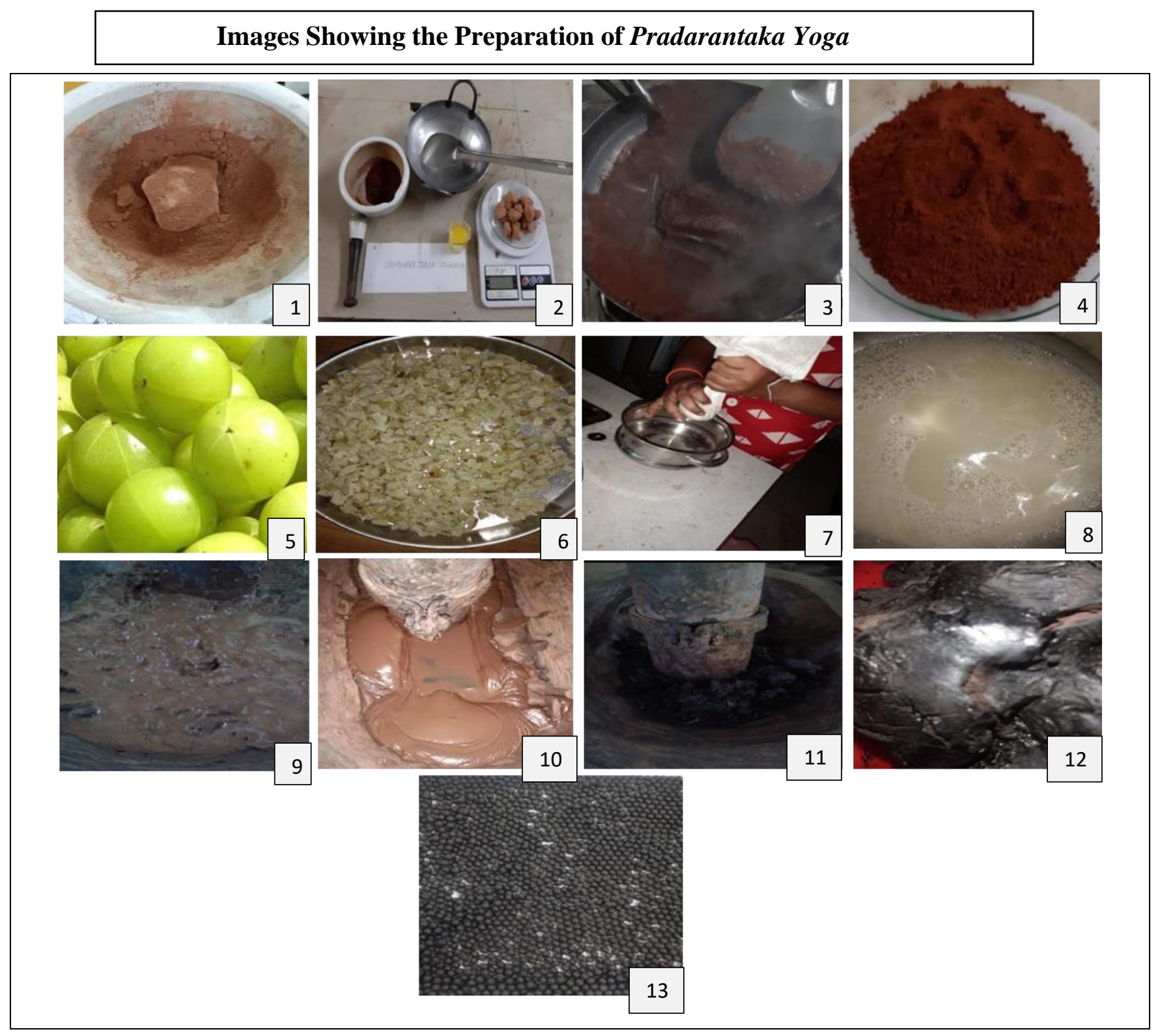


1- Asudha Gairika

2- Sambhara Dravya Sangraha

3- Ghrta bharjana of Ghrta

4- Shoditha Gairika

5- Amalaki

6- Amalaki pieces

7- Squeezing of Swarasa

8- Amalaki Swarasa

9- Day 1 of Bhavana with Amalaki Swarasa

10- $11^{\text {th }}$ day of Bhavana with Amalaki Swarasa
11- $21^{\text {st }}$ day of Bhavana with Amalaki Swarasa

12- After completion of Bhavana with Amalaki Swarasa

13- Vati of Pradarantaka Yoga

\section{Precautions}

- Trituration should be carried out slow and steady to prevent spillage of the material.

- Pills are to be preserved in absolute sterile and moisture-free glass containers.

\section{RESULTS:}

Table 1: Showing the change in weight of various practices in the preparation of Pradarantaka Yoga

\begin{tabular}{|l|l|l|l|}
\hline Name of the practical & Initial weight(g) & Final weight(g) & Gain/Loss in weight (g) \\
\hline Gairika Shodhana & 1400 & 1300 & Loss $100 \mathrm{~g}$ \\
\hline Amalaki Swarasa & $1.5 \mathrm{~kg}$ & $850 \mathrm{ml}$ & Loss $650 \mathrm{~g}$ \\
\hline
\end{tabular}

Table 2: Showing the result of Preparation of Vati of Pradarantaka Yoga

\begin{tabular}{|l|l|l|}
\hline Weight of Pradarantaka Yoga & No. of Total Vati (Each 375 mg) & Loss \\
\hline $2000 g$ & 5300 & $20 \mathrm{~g}$ \\
\hline
\end{tabular}

\section{DISCUSSION}

Most of the materials of Rasa Shastra are obtained from mineral sources containing various impurities which are responsible for causing toxic effects to body tissues. Therefore, as a rule, the Rasa dravyas are purified first by a specialized processing technique known as Shodhana before subjecting them to the main processing. It is done to remove visible and invisible impurities, reduce toxicity and enhance the therapeutic property.

Gairikashodhana

Gairika Shodhana was done according to the method that was mentioned in Rasa Tarngini [2] Fine powder of Swarna Gairika is taken in a clean kadhai (iron vessel) placed over a mild fire. It is added with the needed quantity of ghee and fired properly. The dry powder obtained at the end is stored as suddha Gairika for further pharmaceutical use. Shodhita Gairika showed features like i.e., Nischandrika, Rekhapurna and Varitara which indicate the reduction in particle size due to the trituration process.
Swarasa Nirmana ${ }^{(3)}$

Fresh Amalaki was collected, washed and pulp should be removed. Swarasa was extracted by squeezing the paste of Amalaki Swarasa through a clean cloth, according to the reference mentioned in Sharangadhara Samhita Madhyama Khanda.

Bhavana of Shodhita Gairika with Amalaki Swarasa The homogenous mixture was taken in Khalwayantra and Amalaki swarasa was added and triturated until it attains Vatilakshanas.[4] By Bhavana process, the mixture gets properly mixed, and the material becomes soft, smooth and nonsticky. Bhavana facilitates particle size reduction and homogenization leading to modification of properties (Gunantatradhana) of the end product

\section{Preparation of Pradarantaka Yoga Vati}

According to Rasa Tantra Sara va Siddha Prayoga Sangraha (part 2) dosage of Pradarantaka Yoga is 750mg (twice a day).[5] Bhavana of a Homogenous mixture of $750 \mathrm{mg}$ was taken and rolled between thumb and index finger. 


\section{CONCLUSION}

Pharmaceutical standardization of Rasa Oushadis is an important requisite for the establishment of their efficacy and consistent biological activity. The pharmaceutical procedures involved in this study are Shodhana, Amalaki Swarasa, Bhavana, and the preparation of Vati of Pradarantaka Yoga. Bhavana with herbal liquids helps bring minute particles of materials in contact with each other as well as with liquid media, so Bhavana with Amalaki. Swarasa is considered a best choice

\section{REFERENCES}

1. Krishna Gopala. Rasa Tantra Sara Va Siddha Prayoga Sangraha (part 2) streeroga Prakaranam.Rajasthan; Krishna Gopal Ayurveda Bhavan: P.268

2. Pandita Kashinath Shastry, Rasa Tarangini by Pranacharya Sri Sadananda Sharma, Motilal Banarsidass, New Delhi Reprint:2014; P.596

3. Dr. P. Himasagar Chandra Murthy Sharangadhara Samhita Madhyama Khanda; P.102 Krishna Gopala.Rasa Tantra Sara Va Siddha Prayoga Sangraha (part 2) streeroga

4. Prakaranam. Rajasthan; Krishna Gopal Ayurveda Bhavan: P.268

5. Krishna Gopala Rasa Tantra Sara Va Siddha Prayoga Sangraha (part 2) streeroga Prakaranam. Rajasthan; Krishna Gopal Ayurveda Bhavan: P.268

\section{Source of Support: Nil Conflict of Interest: None Declared}

How to cite this URL: Alukuru Harsitha et al: Pharmaceutical Standardization Of Pradarantaka Yoga. International Ayurvedic Medical Journal \{online\} 2021 \{cited November 2021\} Available from: http://www.iamj.in/posts/images/upload/3195_3199.pdf 